\title{
International Deep Seabed Mining and China's Legislative Commitment to Marine Environmental Protection
}

\author{
Hao Shen*
}

Part XI of the UNCLOS lays out the legal framework for deep seabed mining activities in the Area. Several countries have already passed domestic deep seabed mining laws fulfilling their obligations under the Convention and the regulations promulgated by the ISA, established under the Convention. China passed its own deep seabed mining law in 2016. China's deep seabed mining law aims at securing effective regulation of its sponsored contractors' deep seabed activities and ensuring the contractors' compliance with the rules and regulations issued by the ISA. China's law pays tremendous attention to marine environmental protection during contractors' deep seabed activities. This paper briefly describes the legal regime for international seabed mining, then illustrates China's legislative actions, examines the key environmental provisions of China's deep seabed law and analyzes the balancing of interests of multiple parties behind China's emphasis on marine environmental protection during the exploration and exploitation of deep seabed minerals.

\section{Keywords}

UNCLOS, Deep Seabed, China's Deep Seabed Mining Law, Environmental Protection, State Sponsorship

* Assistant Professor of Law at East China Normal University. LL.B. (ECUPL), LL.M./Ph.D. (Fudan). ORCID: http:// orcid.org/0000-0002-4235-4179. The author may be contacted at: hshen@law.ecnu.edu.cn / Address: 105-6, Building 1, 1298 Changde Rd. Shanghai, P.R. China 200060.

DOI: http://dx.doi.org/10.14330/jeail.2017.10.2.08 


\section{Introduction}

China has a major interest in deep seabed mining. It currently holds four deep seabed areas for mineral exploration and considers expanding its investment in the deep seabed in the future. Since enacting its first Deep Seabed Law in 2016, China has been developing relevant rules and regulations. The purpose of the Deep Seabed Law is to: (1) secure effective regulation of its sponsored contractors' deep seabed activities and ensure the contractors' compliance with the rules and regulations issued by the International Seabed Authority ("ISA"), especially environmental rules and regulations; and (2) provide legal assurance for the contractors engaged in deep seabed activities. In particular, the Deep Seabed Law places much emphasis on marine environmental protection, which is one of the most important aspects of deep seabed mining.

This paper aims to answer the following questions: (1) Why has China been so active in deep seabed mining?; (2) What are the factors (legal and practical) that prompted China to adopt its first Deep Seabed Law and continue its work on developing relevant rules and regulations?; (3) Why is China very committed to marine environmental protection during deep seabed mining?; and (4) how did the interested parties behind deep seabed mining seek to influence the character of the legislation? This paper is composed of six parts including a short Introduction and Conclusion. Parts two, three, and four will discuss the beginning, international response and State sponsorship for the legal regime of international deep seabed mining. Part five will look into China's legislative response to such international legal framework.

\section{The Beginning of Deep Seabed Mining}

In 1965, John L. Mero's book, The Mineral Resources of the SeAs introduced most of the currently available information regarding a kind of seabed resource, called 'manganese nodules,' which is mostly scattered on the seabed floor of the Pacific Ocean and other Ocean floors. ${ }^{1}$ This type of resource had already been discovered in 1873 during the Challenger's Oceanographic Expedition, but it was not until after

1 J. Mero, The Mineral Resources Of The Sea 174-5 (1965). 
World War II that it became technologically possible to commercially explore and exploit the resource. ${ }^{2}$

Manganese nodules contain vast amount of minerals, including copper, cobalt, manganese, and nickel. Mero estimated the amount of manganese nodules and minerals that are contained within them. The international community assumed that once it becomes economically viable to explore and exploit the mineral, the economic and commercial benefits would be immense. ${ }^{3}$ In December 1965, the question of how to utilize the newly discovered minerals was presented at the White House Conference on International Cooperation. There, the Committee on Conservation and Development of Natural Resources submitted a report proposing its initial idea regarding commercially exploring and exploiting the resources in the deep seabed. ${ }^{4}$ The report noted that as the resources are located on the high seas beyond national jurisdictions, two principles - (1) the efficient and orderly exploration and exploitation of the resource and (2) the distribution and sharing of the mining rights - should be considered. ${ }^{5}$ The Committee proposed that producers have exclusive mining rights to areas that are large enough to permit them to operate economically and without fear of congestion or interference. In addition, if the rights are to be granted for resources that are the common property of the global community, then decisions on the allocation of these rights or on the methods of acquisition of rights must be made within the framework of international law. A specialized agency of the United Nations would be thus the most appropriate body for administering the distribution of exclusive mining rights. ${ }^{6}$

In 1966, the Commission to Study the Organization of Peace proposed the General Assembly to declare that the high seas are not to be subject to appropriation by any State. Also, to avoid potential conflicts arising from the use of deep seabed minerals, the UN assumed the responsibility to manage the resources in the deep seabed on behalf of the international community. ${ }^{7}$ The Commission suggested the "United Nations Marine Resources Agency," a specialized organization be established, whose

2 J. Nelson, The Contemporary Seabed Mining Regime A Critical Analysis of the Mining Regulations Promulgated by the International Seabed Authority, 16 Colo. J. InT'L EnvT'L. L. \& PoL'y 30-1(2005).

3 W. Wertenbaker, Mining the Wealth of The Ocean Deep, N.Y. TimEs, July 17, 1977, available at http://www.nytimes. com/1977/07/17/archives/mining-the-wealth-of-the-ocean-deep-multinational-companies-are.html?mcubz=3(last visited on Sept. 16, 2017).

4 R. Gardner, Blueprint for Peace 144 (1966).

5 Id.

Id.

7 S. Nandan \& M. Lodge, The Development of the Regime for Deep Seabed Mining, the official website of the International Seabed Authority, available at https://www.isa.org.jm/files/documents/EN/Pubs/Regime-ae.pdf (last visited on Sept. 16. 2017) 
functions might include controlling and managing international marine resources, holding ownership rights, functioning with the independence and efficiency of the international bank, and distributing the returns from such exploitation, in accordance with directives issued by the General Assembly. ${ }^{8}$ The immense potential economic benefits caught the attention of the US in July 1966. The US President Lyndon Johnson declared:

Under no circumstances, we believe, must we ever allow the prospects of rich harvest and mineral wealth to create a new form of colonial competition among the maritime nations. We must be careful to avoid a race to grab and to hold the lands under the high seas. We must ensure that the deep seas and the oceans bottoms are, and remain, the legacy of all human beings. ${ }^{9}$

Developed countries are technologically capable of engaging in deep seabed activities. Many of them opined the view that they were free to exploit the resources under the principle of Freedom of the High Seas. Conversely, developing countries are worried that resources would be depleted in this course. ${ }^{10}$ The international society has to address how developing countries can secure their marine interests and devise an international mechanism for sustainable exploration and exploitation of the deep seabed resources. ${ }^{11}$

\section{International Response}

\section{A. The Establishment of International Seabed Legal Mechanism}

The vast amount of seabed minerals and their enormous potential for economic benefits have drawn the attention of developed countries that are far more technologically advanced than developing countries. Developing countries were concerned that this might lead to a round of colonization of the deep seabed resources. At the 22nd

\footnotetext{
Id.

9 Remarks by President Lyndon B. Johnson at the Commissioning of the Research Ship-Oceanographer, July 13, 1966, The American Presidency Project, available at http://www.presidency.ucsb.edu/ws/?pid=27711 (last visited on Sept. 16, 2017).

10 Zitai Zhang, Hao Shen \&Wenzhao Zhang, Research on Laws Regulating Exploration and Exploitation of Deep SEABED ResourCES [深海海底资源勘探开发法研究] 5 (2015).

11 Id.
} 
session of the UN General Assembly in 1967, Ambassador of Malta Arvid Pardo declared: "The seabed and the ocean floor a common heritage of mankind." $12 \mathrm{He}$ also suggested immediate steps be taken to draft a treaty to regulate, supervise, and control all activities thereon. ${ }^{13}$

The General Assembly unanimously adopted Resolution 2340 (XXII) on December $18,1967,{ }^{14}$ which recognized "the common interest of mankind in the seabed and the ocean floor, which constitute the major portion of the area of this planet." ${ }^{\prime 15}$ In this Resolution, the General Assembly declared:

The exploration and use of the sea-bed and the ocean floor, and the subsoil thereof ... should be conducted in accordance with the purposes and principles of the Charter of the United Nations, in the interest of maintaining international peace and security and for the benefit of all mankind. ${ }^{16}$

This basic principle on the deep seabed was reflected in the original rules regarding deep seabed mining in the Area ${ }^{17}$ in Part XI of the draft UNCLOS. However, developed countries were not satisfied with these provisions. After long consultations, ${ }^{18}$ compromises were adopted between developing and developed countries, as with the "Agreement relating to the Implementation of Part XI of the United Nations Convention on the Law of the Sea of December 10, 1982 (hereinafter 1994 Implementing Agreement)," which modified the majority of the original provisions of Part XI. This was finally passed as a part of the Convention.

\section{B. International Seabed Authority}

There are generally three stages of deep seabed activities in the Area: prospecting, exploration, and exploitation. Prospecting shall be conducted only after the ISA has received a satisfactory written agreement that the proposed prospector will comply with the UNCLOS and the relevant rules, regulations and procedures of the ISA. ${ }^{19}$

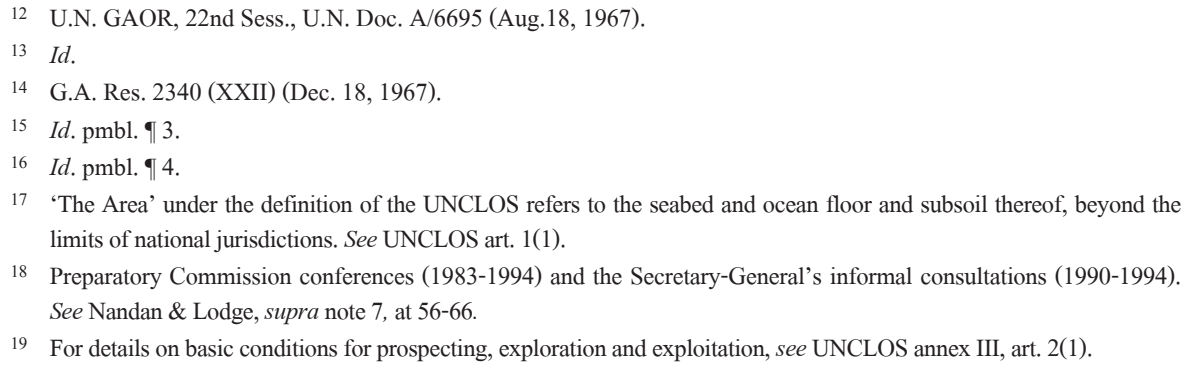


Exploration and exploitation shall be carried out only in areas specified in plans of work and approved by the ISA, in accordance with this Convention and the relevant rules, regulations and procedures of the ISA. ${ }^{20}$ Upon its approval by the ISA, every plan of work, except for those presented by the Enterprise, ${ }^{21}$ shall be in the form of a contract of exploration and exploitation between the ISA and the applicant(s). ${ }^{22}$

The ISA was established under Article 153 of the UNCLOS as the main governing body. All Member States to the Convention are the members of the ISA. ${ }^{23}$ The ISA is responsible for both administering deep seabed activities, and promulgating rules and regulations regarding exploration and exploitation of deep seabed minerals. ${ }^{24}$ The Agency also bears the responsibility for supervising parties that are engaged in deep seabed activities, protecting the marine environment, encouraging marine scientific research, and protecting the seabed cultural heritage. ${ }^{25}$

To date, the ISA has issued the Regulations on Prospecting and Exploration for Polymetallic Nodules in the Area (July 13, 2000), which was later updated on July 25, 2013; Regulations on Prospecting and Exploration for Polymetallic Sulphides in the Area (May 7, 2010); and Regulations on Prospecting and Exploration for Cobalt-Rich Crusts (July 27, 2012). ${ }^{26}$

The regulations for exploiting the three types of minerals are still under discussion. Final Regulations for Exploitation of Mineral Resources in the Area is the ultimate regulatory phase in developing the common heritage of mankind and implementing the Mining Code in its entirety. Since 2013, the Authority has made significant progress. Recent activities includes a Stakeholder Survey, issuance of consultation documents, discussion papers, and targeted workshops related to the development of specific areas of the Exploitation Code. In March 2015 and July 2016, the ISA issued two reports containing two drafts of the regulations for the

20 Id. art. 3(2).

21 The ISA not only conducts its own mining operations for the benefit of developing countries through its operating arm, called the 'Enterprise,' but also contracts with private and state ventures to give them mining rights in the area. As a result, the private and state ventures can operate in parallel with the ISA.

22 UNCLOS annex III, art. 3(5).

23 S. Vasciannie, Part XI of the law of the sea of Convention and third states: some general observations, 48 CAMBRIDGE L. J. 85 (1989).

24 J. Harrison, The International Seabed Authority and the Development of the Legal Regime for Deep Seabed Mining, University of Edinburgh School of Law Working Paper No. 2010/17, available at https://papers.ssrn.com/sol3/papers. cfm?abstract_id=1609687 (last visited on Oct.5, 2017).

25 UNCLOS art. 137(2). For details, see T. Scovazzi, Mining, Protection of the Environment, Scientific Research an Bioprospecting: Some Considerations on the Role of the International Seabed Authority, 19 INT'L J. MARINE \& COASTAL L. 383-409 (2004).

26 ISA, The Mining Code, available at https:/www.isa.org.jm/mining-code/Regulations (last visited on Sept.16, 2017). 
exploitation activities in the Area to the members of the ISA and all stakeholders. ${ }^{27}$

\section{States Sponsorship}

It is a prerequisite for the applicants to obtain a certificate of sponsorship from a sponsoring state before signing contracts for exploration and exploitation with the ISA or becoming contractors engaged in deep seabed activities. Articles 139(2) and 153(4) of the UNCLOS provide the legal basis for the sponsorship of States parties. Article 4(4) of Annex III also refers to the responsibility of sponsoring State to ensure the activities of a contractor in the Area "in conformity with the terms of its contract and its obligations under this Convention." Reading these provisions together, the author can draw the following conclusions:

a) Sponsoring states have the responsibility to take all necessary and appropriate measures to ensure sponsored parties' (contractors) compliance with all of the regulations.

b) "All necessary and appropriate measures" refer to adopting laws and regulations and taking administrative measures which are, within the framework of its legal system, reasonably appropriate for securing compliance by persons under its jurisdiction.

c) A State Party shall be liable if: 1) the state has not fulfilled its responsibilities as a sponsoring state; 2) there is damage caused by contactors; or 3) there is causation between the state's failure to fulfill its responsibility as a sponsor and the damage. However, a State Party shall not be liable for damage caused by any failure to comply with the relevant rules by a person whom it has sponsored if the State Party has taken all necessary and appropriate measures to secure effective compliance under Article 153, paragraph 4, and Annex III, Article 4, paragraph 4.

In 2011, the International Tribunal for the Law of the Sea ("ITLOS") was asked to provide an advisory opinion on the legal responsibilities of sponsoring States and any liability associated with failure to comply with those requirements. ${ }^{28}$ The key findings

27 ISA, Developing a Regulatory Framework for Mineral Exploration in the Area (2015), available at http://www.isa. org.jm/files/documents/EN/Survey/Report-2015.pdf; Developing a Regulatory Framework For Mineral Exploration IN THE AREA (2016), available at https://www.isa.org.jm/files/documents/EN/Regs/DraftExpl/Draft_ExplReg_SCT.pdf (all last visited on Oct. 5, 2017).

28 I. Plakokefalos, Seabed Disputes Chamber of the International Tribunal for the Law of the Sea, 24 J. ENVT'L. L. 13344 (2012). See also T. Poisel, Deep Seabed Mining: Implications of Seabed Disputes Chamber's Advisory Opinion, 19 Australian InT'L L. J. 213-33(2012); D. Freestone, Advisory Opinion of the Seabed Disputes Chamber of International Tribunal for the Law of the Sea on "Responsibilities and Obligations of States Sponsoring Persons and Entities with 
of the ITLOS are as follows:

a) The duty to ensure compliance is an obligation of due diligence; ${ }^{29}$

b) What will be considered sufficiently diligent will be impacted by the risk levels associated with the activity in question; riskier activities, such as exploitation activities, require a higher degree of oversight and care; ${ }^{30}$

c) Due diligence requires both the adoption of laws and regulations and the taking of "administrative measures" for securing compliance; ${ }^{31}$

d) Without seeking to define the full content of the due diligence obligation, it does include the direct obligations to adopt a precautionary approach, to use best environmental practices and to require the preparation of an Environmental Impact Assessment (EIA) $;^{32}$

e) Due diligence obligations in the context of activities in the Area are not differentiated on the basis of development status; and ${ }^{33}$

f) Sponsoring states may be liable for damages that result from their failure to carry out their legal responsibilities. ${ }^{34}$

State sponsorship is manifested in all the foreign domestic deep seabed laws. ${ }^{35}$ Potential contractors need to meet certain requirements to be awarded the certificate of sponsorship. The said certificate is a prior condition necessary for potential contractors to establish an exploration or exploitation contract with the ISA.

The ISA has already started its process of promulgating regulations for the exploitation of these minerals. Furthermore, there are still many scientific uncertainties regarding deep seabed mining, such as the impact of the activities to marine environment and marine life. The international deep seabed regime is rapidly evolving and developing. At the same time, dozens of countries have already enacted, or are in

respect to Activities in the Area,"15:7 ASIL Insights (2011), available at https://www.asil.org/insights/volume/15/ issue/7/advisory-opinion-seabed-disputes-chamber-international-tribunal-law-sea- (last visited on Oct. 3, 2017).

29 ITLOS Seabed Disputes Chamber, Case No. 17, Responsibilities and Obligations of States Sponsoring Persons and Entities with Respect to Activities in the Area, Advisory Opinion (Feb. 1, 2011), ๆ 110, available at https://www.itlos. org/fileadmin/itlos/documents/cases/case_no_17/adv_op_010211.pdf (last visited on Oct.5, 2017).

$30 \quad$ Id. 117.

31 Id. 1119.

32 Id. 125.

33 Id. 158.

34 Id. 189.

35 See, e.g., UK: Deep Sea Act (2014); Fiji: International Seabed Mineral Management Decree (2013); Singapore: Deep Seabed Mining Bill (2015); Tonga Seabed Minerals Act (2014); Czech Republic: Prospecting, Exploration for and Exploitation of Mineral Resources from the Seabed beyond Limits of National Jurisdiction(2000); Belgium: Law on Prospection, Exploration and Exploitation of Resources of Seabed and Sub-soil thereof Beyond Limits of National Jurisdiction (2013); Nauru: International Seabed Minerals Act 2015; Tuvalu: Seabed Minerals Act (2014). 
the process of enacting domestic laws to fulfill their responsibilities as sponsoring States.

\section{China's Legislative Response}

China, being a State party to the UNCLOS, is fully aware of the potential economic benefits. It has been actively engaged in the practice of prospecting and exploring deep seabed minerals in coordination with the ISA. The China Ocean Mineral Resource R\&D Association ("COMRA"), sponsored by the Chinese government, signed a 15-year exploration contract for polymetallic nodules with the ISA on May $22,2001 .^{36}$ During the seventeenth annual session of the ISA in 2011, the Seabed Authority Council approved the plans of work of the COMRA for polymetallic sulfides in the Area. The ISA and the COMRA signed a 15-year contract in Beijing on April 29, 2014 regarding the exploration of cobalt-rich ferromanganese crust. It made the COMRA the second entity to have a contract with the ISA for the exploration of cobalt-rich ferromanganese. This makes the COMRA the only contractor currently operating in the Area with regard to all three types of minerals.

On August 8, 2014, the Secretary-General of the ISA received an application from the China Minmetals Corporation for the approval of a plan of work for the exploration of polymetallic nodules in the Area. After a thorough review of the plan of work, the Legal and Technical Commission recommended approval to the Council for the plan of work for exploration of polymetallic nodules as submitted by China Minmetals Corporation. A 15-year exploration contract for polymetallic nodules was signed between the China Minmetals Corporation and the ISA in May 2017.37

With all the deep seabed activities currently ongoing, China has intensively enacted domestic laws and issued relevant rules to regulate the deep seabed activities of the contractors under its sponsorship. The PRC Law on Exploration and

36 Upon the application of COMRA to the ISA, the exploration contract of polymetallic nodules has been extended for 5 years starting from May 22, 2016. See Decision of the Council of the International Seabed Authority on the Application of the COMRA to extend the application of the COMRA and the Authority's polymetallic nodule exploration contract [国际海底管理局理事会关于中国大洋矿产资源研究开发协会提出的延长中国大洋矿产资源研究开发协会与 管理局多金属结核勘探合同的申请的决定], available at http://www.comra.org/2016-08/04/content 8940025.htm (last visited on Oct. 5, 2017).

37 See China Minmetals Corporation Signs Exploration Contract with the International Seabed Authority, ISA NEws, May 12, 2017, available at https://www.isa.org.jm/news/china-minmetals-corporation-signs-exploration-contractinternational-seabed-authority (last visited on Oct. 3, 2017). 
Exploitation of Deep Seabed Area Resources (hereinafter Deep Seabed Mining Law) was adopted at the 19th session of the 12th National People's Congress on February 26, 2016, which became effective as of May 1, 2016.

\section{A. The Establishment of the Office of the COMRA}

In the early 1990s, China established the Office of the COMRA, within the State Oceanic Administration which functioned as the agency administering China's deep seabed activities in the Area. As the COMRA ${ }^{38}$ is a major contractor sponsored by the Chinese government engaging in the exploration of resources in the Area, the Office of the COMRA has been charged with administrative responsibilities for promulgating relevant rules and regulations, supervising activities that have been taking place on international waters, ensuring compliance with the Convention, and other international laws and customs.

\section{B. Relevant Laws in China}

Before its deep seabed law was adopted, China already had several resource and mineral exploration and exploitation laws, although these existing laws only regulated mining activities within China's national jurisdiction. China has submitted the list of laws to the Secretariat of the ISA at the request of the Council of the ISA as follows: ${ }^{39}$

1. Mineral Resources Law of the People's Republic of China (Adopted at the 15th meeting of the Standing Committee of the Sixth National People's Congress on 19 March 1986, and revised in accordance with the Decision of the Standing Committee of the National People's Congress on Revising the Mineral Resources Law of the People's Republic of China, adopted at the meeting of the Standing Committee of the Eighth National People's Congress on 29 August 1996).

2. Rules for Implementation of the Mineral Resources Law of the People's Republic of China (Promulgated by Decree No. 152 of the State Council of the People's Republic

38 Since the establishment of the COMRA on April 9, 1990, under the leadership of the State Oceanic Administration and the Executive Council of the Association, with the guidance and strong support of the various departments of the State, the COMRA has carried out international maritime work in various fields and has made tremendous progress in safeguarding international maritime rights and interests, the development of international seabed resources, the development of deep-sea high-tech, participation in international maritime affairs, etc. See Brief introduction of COMRA [中国大洋矿产资源研究开发协会简介], available at http://www.comra.org/2013-09/23/content_6322477. htm (last visited on Oct. 5, 2017).

39 ISA, Decision of the Council of the International Seabed Authority, ISBA/17/C/20 (July 21, 2011), available at http:// www.isa.org.jm/files/documents/EN/17Sess/Council/ISBA-17C-20.pdf (last visited on Oct. 3, 2017). 
of China on 26 March 1994, and effective as of the date of promulgation).

3. Marine Environmental Protection Law of the People's Republic of China (Adopted at the twenty-fourth session of the Standing Committee of the Fifth National People's Congress on 23 August 1982; effective as of 1 March 1983, and revised at the thirteenth session of the Standing Committee of the Ninth National People's Congress on 25 December 1999).

4. Administrative Regulation on the Prevention and Treatment of the Pollution and Damage to the Marine Environment by Marine Engineering Construction Projects (Promulgated by the State Council on 25 March 2010 and in force on the same day).

As can be inferred from the titles of the existing laws, the jurisdiction of all the existing relevant laws is within national boundaries, none of which is suited to regulating deep seabed activities in the Area. However, drafting the existing laws has allowed the government to accumulate, to a certain degree, some experience that may shed light on drafting a deep seabed law in China. Moreover, some legal mechanisms in the existing laws could be embodied in China's own deep seabed law, such as the legal mechanisms of permits and environmental protection. ${ }^{40}$

\section{China's Deep Seabed Mining Law: A Marine Environmental Protection Oriented Legislation}

After the second reading of the draft deep seabed law, the "Law of People's Republic of China on Exploration and Exploitation of Deep Seabed Area Resources" was adopted in February 2016 and came into effect in May 2016. ${ }^{41}$

\section{Principles for Drafting of China's Deep Seabed Law}

In the course of drafting China's deep seabed law, there has been much debate between legislators and scholars regarding the basic principles. Although, those maintained vastly different views in this respect, the following three principles were maintained for drafting of the law, namely, standardization, coordination, and incentive.

\section{Standardization}

In addition to fulfilling its responsibility as a sponsoring State under the UNCLOS,

40 ZhANG, SHEN \& Zhang, supra note 10, at 184.

41 Law of People's Republic of China on Exploration and Exploitation of Deep Seabed Area Resources(China's Deep Seabed Law) [中华人民共和国深海海底资源勘探开发法], available at http://www.soa.gov.cn/zwgk/fwjgwywj/ shfl/201602/t20160229_50172.html (last visited on Sept.16, 2017). 
China aimed at enacting a deep seabed law in order to standardize the procedures for the contractors engaged in deep seabed activities as well as provide the guidance for potential applicants interested in the exploration and exploitation activities in the Area. Keeping that purpose in mind, China's deep seabed law should be procedureoriented, which provides the details of the rights and obligations among the three parties such as the domestic deep seabed regulatory agency, the ISA, and the potential applicants (potential contractors).

\section{Coordination}

A unique element of the domestic deep seabed law is that it must procedurally connect with the international legal regime for deep seabed mining devised by the ISA under the UNCLOS. Both domestic deep seabed law and relevant international laws would apply to potential applicants of deep seabed activities. Domestically, potential applicants should contact China's national deep seabed regulation agency and go through certain procedures to obtain state sponsorship. Internationally, the applicants should submit plans of work, the certificate of state sponsorship, and other required documents to the ISA, which will determine if the applicants are eligible to be granted exploration/exploitation contracts. Therefore, the whole procedure for deep seabed activities in the Area involves three parties and two regulatory dimensions (national and international procedures). The connection and coordination between the two responsible agencies (the domestic agency and the ISA) are essential to create some complexity in the drafting of national legislation.

\section{Incentive}

To safeguard China's marine interests and encourage more entities, regardless of private or state-affiliated parties who engage in deep seabed activities, China's deep seabed law should provide entities with incentives to engage in these activities. The common incentive practices include tax deductions, government purchases, and government-sponsored debt for those who are engaged in deep seabed activities, etc.

Providing 'incentive provision' is a common practice in China's environmental legislation. Article 11 of the newly amended Environmental Protection Law ${ }^{42}$ states that the government shall reward those work units and individuals who have significantly contributed to environmental protection. This is an example of an incentive provision.

Similar provisions can also be found in other laws in China. Article 7 of the Clean

42 The Environmental law was amended in 2014, and the amendment became effective on the first day of 2015. 
Energy Act states that State Council shall promulgate financial rules and policies in order for lower levelled government to promote the practice of clean production and enact such rules. Chapter Four of the Clean Energy Act lists all these incentive measures that should be adopted by the government to promote the use of clean energy and the practice of clean production. Those measures include, but are not limited to, rewards for the foundation building of clean energy, tax deductions, and governmental procurement ${ }^{43}$ The Energy Conservation $\mathrm{Act}^{44}$ and the Renewable Energy Act ${ }^{45}$ also contain incentive provisions to promote the conservation of energy and the use of renewable energy.

As illustrated, it is a common practice in China to include incentive measures in areas such as environmental protection, energy conservation, renewable energy, and clean production. The government usually adopts a bottom-up approach to get the public involved in order to promote achievement of certain ends. Considering the vast amount of resources that are embedded in the deep ocean, the government should essentially get private parties motivated and actively engaged in deep seabed mining activities. In addition, the incentive measures should be understood in regard to the following three fronts of incentives for: (1) technological research and development; (2) investment in deep seabed exploration and exploitation activities; and (3) marine environmental protection.

\section{Marine Environmental Protection-oriented Legislation}

China's deep seabed law comprises seven chapters: General Provisions, Exploration and Exploitation, Environmental Protection, Scientific and Technological Research and Resource Prospection, Supervision and Inspection, Liability, and Supplementary Provisions. ${ }^{46}$ Having 29 articles, it is considered rather shorter than similar legislations in other countries. Most of legal institutions that are embodied in China's deep seabed law are set in rather general terms. As a common practice in China, there will be presumably regulations promulgated by the State Council to fill the remaining loopholes.

Enacting a deep seabed law is the first step that China has taken to regulate the deep seabed activities conducted by sponsored contractors. The deep seabed law establishes the Oceanic Administrative Department of the State Council as the

\footnotetext{
43 Zitai Zhang, New Thought on the Revision of <The Energy Conservation Act > in China [我国《节约能源法》修订的 新思维], 2 LEGAL SCI. [法学] (2007).

44 Energy Conservation Act, ch. 5.

45 Renewable Energy Act, ch. 6.

46 China's Deep Seabed Law, supra note 41.
} 
domestic agency administering the deep seabed law. Potential contractors including citizens, legal entities or other organizations of China ${ }^{47}$ should apply for permits or licenses from the Oceanic Administrative Department of the State Council before filing applications with the ISA to engage in exploration and exploitation of deep seabed area resources. ${ }^{48}$

Deep seabed activities involve significant scientific uncertainty, although marine scientific research is developing by leaps and bounds. As mankind does not fully understand the ocean, some State parties to the UNCLOS have employed a precautionary approach in their own domestic deep seabed laws. ${ }^{49}$ Article 145 of the UNCLOS addresses marine environmental protection, which gives the ISA power to adopt rules, regulations, and procedures for the prevention, reduction and control of pollution, and other hazards to the marine environment from activities in the Area. Applying the ISA's basic obligation of protecting the marine environment found in Article 145 of the Convention and the 1994 Implementation Agreement, the three sets of Regulations on Prospecting and Exploration for three types of deep seabed minerals spell out, in considerable details, the obligations of contractors, sponsoring States, and the ISA with respect to the protection and preservation of the marine environment. ${ }^{50}$

Notably, China's deep seabed law requires marine environmental protection during the contractors' activities. Provisions regarding the protection of the marine environment and bio-diversity are included in different sections of the law. Actually, the word 'environment' has appeared more than 20 times in this 29-article's law.

First, in the first chapter (General Principles) of China's deep seabed law, Article 1 stipulates that one of the purposes of enacting this law is to protect the marine environment and promote the sustainable use of deep seabed area resources. Article 3 lays out the principles under which exploration and exploitation of deep seabed area resources should be conducted, stressing the principle of environmental protection. In addition, the State shall, in accordance with Article 4, advance the capacity for exploring and exploiting resources and marine environmental protection. Additionally, in Article 6, the State shall encourage international cooperation with

47 Id. art. 2.

48 Id. art. 7.

49 See, e.g., Fiji International Seabed Mineral Management Decree (2013), art. 2, available at http://www.isa.org.jm/ files/documents/EN/NatLeg/Fiji2013.pdf (last visited on Oct. 5, 2017). Here, 'Precautionary Approach' means that to protect the environment, where there are threats of serious or irreversible damage, lack of full scientific certainty shall not be used as a reason for postponing cost-effective measures to prevent environmental degradation.

50 Provisions for protecting the marine environment are also included in 1994 Implementation Agreement. See 1994

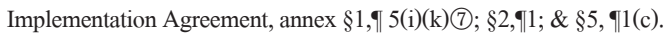


respect to environmental protection.

Second, Chapter 3 (Environmental Protection) of China's deep seabed law is devoted to marine environmental protection. Measures for marine environmental protection have been embodied in this chapter, such as environmental baselines, environmental impact assessments, and environmental monitoring. Necessary measures should be taken to protect and preserve the rare or vulnerable ecosystems, the living environment of endangered, threatened or extinction-prone species, and other marine living organisms. Chapter 3 comprises Articles 12, 13 and 14, all of which burden contractors with the responsibility of taking measures for environmental protection. Article 12 emphasizes the role of advanced technology with regard to environmental protection. It also stipulates that contractors shall utilize the advanced technology of exploration and exploitation accessible to prevent, mitigate and control the pollution and damages that may cause to the marine environment. Article 13 lays down legal institutions for establishing environmental baselines, assessing environmental impact, and monitoring environmental damage, all of which have been incorporated into the regulations on exploration of deep seabed resources issued by the ISA. Article 14 addresses the issue of protecting marine bio-diversity and utilizing the marine resources under the principle of 'sustainability.' The 'sustainability' is not a new concept; it has been widely accepted and emphasized by the international community in different global, regional, and domestic areas as a guiding navigation for balancing economic development and environmental protection. Through its use in a variety of international treaties and declarations, the principle of 'sustainability' has even achieved the status of customary international law. Article 14 of China's Deep Seabed Law stresses that the use of marine resources by this generation should not threaten the future generations, as the Convention has defined the resources in the Area as the "common heritage of mankind." ${ }^{51}$ As 'Mankind' in Article 136 of the UNCLOS should include the current and future generations, the principle of 'sustainability' is the key to harmonizing the inter-generational conflict.

Third, provisions regarding marine environmental protection also appear in different sections of China's deep seabed law:

a. Chapter 2 (Exploration and Exploitation): Article 7 requires applicants to submit to the Oceanic Administrative Department of the State Council the work plans for exploration and exploitation, including relevant documents pertaining to the impacts that exploration and exploitation might impose on the marine environment, and 
the emergency plans for severe marine environmental damages. Articles 9 and 11 include marine environmental protection as one of the obligations that contractors have to fulfill, requiring contractors to initiate emergency plans and take all practical and reasonable measures to prevent, mitigate and control the damages to the marine environment in circumstances where incidents result in severe marine environmental damage.

b. Chapter 5 (Supervision and Inspection): Article 20 requires contractors to report the status of environmental monitoring to the Oceanic Administrative Department of the State Council, which also has the authority to supervise and inspect the status of contractors' implementing measures for marine environmental protection during deep seabed activities.

c. Chapter 6 (Liability): Articles 23-26 include provisions stating that in circumstances where contractors have failed to fulfill the obligation of marine environmental protection, the contractors shall be liable civilly, administratively or even criminally.

As the legislators were well aware of the uncertain impact that deep seabed activities may have upon the marine environment, they were drafting the law with the conviction that the environmental protection measures of China's deep seabed law should not be less stringent than international standards. ${ }^{52}$ The legal mechanism of environmental protection in China's deep seabed law will be further enriched by the regulations to be promulgated by the oceanic authorities such as "Regulations on Environmental Survey and Environmental Impact Assessment of the Exploration and Exploitation of the Resources in Deep Seabed Area." ${ }^{53}$ Legislators have accumulated a great deal of experiences through existing laws and regulations regarding marine environmental protection such as the "Law of the People's Republic of China on Marine Environmental Protection" and the "Administrative Regulation on the Prevention and Treatment of the Pollution and Damage to the Marine Environment by Marine Engineering Construction Projects." They have devised many legal mechanisms to address possible environmental problems during the utilization of marine resources, such as cap and trade for marine pollution, ${ }^{54}$ standards for marine environmental quality, ${ }^{55}$ incident reporting, ${ }^{56}$ and emergency plans for major marine

52 Zongyu He, Jinggao Lin, Baohua Yang \& Shaojun Liu, Progress and Proposals of Mining Regulations in International Seabed [国际海底区域采矿规章制定的进展与主张], 10 PAC. J. [太平洋学报] 15 (2016).

53 Regulations on Permits of the Exploration and Exploitation of the Resources in Deep Seabed Area [深海海底区域 资源勘探开发许可管理办法], promulgated by State Oceanic Administration on April 27, 2017, available at http:// www.soa.gov.cn/Zwgk/gfxwj/jddy/201705/t20170503_55849.html (last visited on Sept. 16, 2017).

54 PRC Marine Environmental Protection Law [中华人民共和国海洋环境保护法], art. 3.

55 Id. art. 10.

$56 \quad I d$. art. 17. 
pollution incident. ${ }^{57}$ These legal mechanisms in existing laws and regulations have laid a solid foundation for devising adequate mechanisms for marine environmental protection during deep seabed activities.

\section{The Balancing of Interests behind China's Environment-friendly Approach}

\section{State}

As a sponsoring State, China should take precautionary measures, use best environmental practices, and conduct environmental impact assessments. In addition, China needs to ensure that its sponsored contractors abide by all the relevant rules and regulations issued by the ISA. ${ }^{58}$

The contractors must follow two levels of laws and regulations. On the international side, the contractors' activities have to comply with the rules issued by the ISA, while on the domestic side, laws and regulations promulgated by States parties need to be followed. The environmental rules and regulations promulgated by China's State Oceanic Administration are important as good as those issued by the ISA regarding the environmental measures that contractors need to take. Given that China is actively encouraging potential contractors to engage in the exploration and exploitation of deep seabed resources, China should fulfil its obligation as a State sponsor, while not discouraging contractors from engaging in deep seabed activities through setting too stringent environmental standards. The environment-related provisions are all set in rather general terms in China's deep seabed law, which leaves a great deal of room for the State Oceanic Administration to formulate and promulgate rules and regulations in a more detailed manner.

Among the countries that have an interest in deep seabed resources, China currently holds the most contracts with the ISA. E.g., the COMRA signed three exploration contracts regarding all three types of minerals and the China Minmetals Corporation signed one exploration contract for polymetallic nodules with the ISA. With this much at stake in the exploration and exploitation of deep seabed minerals, the Chinese government should make voice for shaping the international seabed regime, especially the regime for exploiting the resources in the Area.

By emphasizing the protection of marine environment in deep seabed activities

$57 \quad$ Id. art. 18.

58 Address by Hao Lu (Director of the NPC Environmental and Resources Protection Committee [全国人大环境 与资源保护委员会主任委员陆浩], A Statement Regarding the Draft of Law of People's Republic of China on Exploration and Exploitation of Deep Seabed Area Resources [关于《中华人民共和国深海海底资源勘探开发法 (草案) 的说明》], The Seventeenth Meeting of the Standing Committee of the Twelfth National People's Congress [第 十二届全国人民代表大会常务委员会第十七次会议], Oct. 30, 2015, available at http://www.npc.gov.cn/npc/lfzt/ rlyw/2015-11/09/content_1950725.htm (last visited on Oct. 5, 2017). 
and manifesting this principle in the deep seabed law, China could promote its image for protecting marine environment in deep seabed activities. It shows that China will not solely exploit the resources but consider marine environmental protection, while designing and shaping the international legal regime for utilizing deep seabed resources.

The international legal regime for deep seabed mining is currently under construction. With the three regulations for exploring the three types of resources already in place, the ISA has been drafting the regulations for exploiting deep seabed resources. In particular, the Agency has been drafting two separate sets of regulations, namely, the 'Environmental Regulations' and the "Seabed Mining Directorate Regulations." 59 These two regulations, along with all others, will be the building blocks for the full regulatory code issued by the ISA. They are commonly referred as the 'Mining Code.'

\section{Potential Contractors}

As mentioned before, of the four exploration contracts that China has concluded with the ISA, three were signed by the COMRA and the other one (fourth) was signed by the China Minmetals Corporation. The China Minmetals Corporation is a state-owned enterprise specializing in the production and trading of metals and minerals under the direct supervision of the State-owned Assets Supervision and Administration Commission. Today, China's deep seabed mining law applies to “citizens, legal entities or other organizations of People's Republic of China that are engaged in exploration and exploitation of deep seabed area resources." ${ }^{\prime 60}$ The Chinese government encourages citizens and private companies to engage in mineral exploration and exploitation in the deep seabed, as well. However, it is not financially feasible under the current circumstances for citizens or private companies to do so.

The stringent environmental measures required by the Chinese government could be a burden for private companies. The China Minmetals Corporation, being a state-owned corporation, needs more resources available to meet the financial and environmental requirements for the certificate of state sponsorship. In this regard, on one hand, the Chinese government should take the measures to meet the ISA's international standards for marine environmental protection during deep seabed mining, while, on the other, it should not ask the sponsored contractors to take too

\footnotetext{
59 isa, Developing a Regulatory Framework for Mineral Exploitation in the Area: Report to members of the AutHority AND ALL STAKEHOLDERs, July 2016, available at https:/www.isa.org.jm/files/documents/EN/Regs/DraftExpl/ Draft_ExplReg_SCT.pdf (last visited on Sept. 16, 2017).

60 China's Deep Seabed Law, art. 2.
} 
many environmental obligations. As a result, the Chinese government will have to carefully draw a line while delineating the environmental measures to be adopted.

\section{Environmental Groups}

Given that marine environment protection is such a significant issue in deep seabed mining, a governmental decision to grant state sponsorship or a license/permit for the exploration/exploitation can sometimes be challenged by pro-environmental groups if they claim that environmental measures have not been adequately adopted. Such a case has been filed in a US court. ${ }^{61}$ The Center for Biological Diversity has brought a civil action for declaratory and injunctive relief against Penny Pritzker, Secretary of Commerce as well as the US National Oceanic and Atmospheric Administration ("NOAA"), regarding NOAA's decision to grant two exploratory licenses for mining in the deep ocean without analyzing the environmental effects of doing so. ${ }^{62}$ The two parties have reached a settlement agreement under the condition that NOAA conducts a supplemental environmental analysis if and when the licensee seeks to conduct at-sea exploration activities. ${ }^{63}$ However, it is unlikely that such cases would appear in China, because there has not been much reports on environmental groups voicing concerns about the impact or even the damage that deep seabed mining may cause to the marine environment.

\section{Prospect}

The terms of the environmental provisions in China's deep seabed law are rather general as set out at Article 13. Potential applicants thus would not know how to engage in these actions by simply reading these general provisions. The State Oceanic Administration is currently in the process of drafting and reviewing the guidelines for conducting these environmental actions during the exploration of deep seabed minerals. The guidelines will instruct potential contractors on how

61 Complaint for Declaratory and Other Relief, Center for Biological Diversity v. Penny Pritzker (US Secretary of Commerce) \& National Oceanic and Atmospheric Administration, (2015) U.S. Dist. Colum., available at http://www. biologicaldiversity.org/campaigns/deep-sea_mining/pdfs/Deep-seabedMiningComplaint_05-12-2015.pdf (last visited Sept.16, 2017). Even though the US is not a party to the UNCLOS, it has been very involved in deep seabed mining. There are basically two ways that the US has engaged in deep seabed mining: (1) US Corporations set up subsidiaries in countries that are parties to the Convention, and the subsidiaries apply for the sponsorship certificate in that country; and (2) Corporations apply for exploration/exploitation permits from NOAA under the 1980 Deep Seabed Hard Mineral Resources Act, which provides the background for the suit filed by the Center for Biological Diversity.

62 Id.

63 See The Settlement Agreement, available at http://www.minerallawblog.com/wp-content/uploads/sites/448/2017/05/ CBD-settlement-agreement.pdf (last visited on Oct. 5, 2017). 
to take the aforementioned environmental measures, such as the data collection to establish marine environmental baselines and the items monitoring during/after the exploration. The guidelines are expected to be promulgated in 2017. ${ }^{4}$

In the coming years, there would be constant changes and updates to these guidelines as marine environmental science develops, especially after the ISA promulgates regulations for the exploitation of deep seabed minerals.

\section{Conclusion}

Tremendous amounts of minerals are embedded in the Area. They are of potentially enormous economic significance. As land-based resources are rapidly depleting, mankind is keeping eyes on the ocean as a source for future mineral resources. The international community has been discussing how to utilize the vast amounts of resources deep in the ocean since the 1960s and Part XI of the UNCLOS has laid a legal foundation for the exploration and exploitation of the resources in the Area, characterized as the "common heritage of mankind." The ISA, established under the UNCLOS, functions as the main administrative body for deep-sea activity governance. On the international side, the ISA has already promulgated three major regulations regarding the exploration of three types of deep-sea minerals. On the domestic side, meanwhile, many countries either have already enacted laws, or are beginning the relevant legislative process to fulfill their obligations as sponsors for contractors that are engaged in deep seabed activities.

To safeguard its maritime interests under international law, China has passed its own deep seabed mining law. China's deep seabed mining law was drafted for the purpose of coordinating national laws with the international regulations issued by the ISA. It aims at both securing effective regulation of its sponsored contractors' deep seabed activities, and ensuring the contractors' compliance with the rules and regulations issued by the ISA (especially environmental rules and regulations). China's deep seabed mining law pays enormous attention to marine environmental protection during contractors' deep seabed activities. Legal provisions to prevent, mitigate and control marine environmental protection are included in different sections of the law. Chapter 3 of the law is especially reserved for establishing legal

64 See State Oceanic Administration interprets Regulations on Permits of the Exploration and Exploitation of the Resources in Deep Seabed Area [海洋局解读《深海海底区域资源勘探开发许可管理办法》], available at http:// www.scio.gov.cn/xwfbh/gbwxwfbh/xwfbh/hyj/Document/1550582/1550582.htm (last visited on Sept. 16, 2017). 
mechanisms for marine environmental protection. As the resources in the Area are the "common heritage of mankind," China's deep seabed law should require the contractors to follow the principle of 'sustainability' during the exploration and exploitation of deep seabed resources. 
